initially appointed by President Ford and was retained by President Carter; he had previously indicated that, even if Carter won, he would probably leave some time next year.

At NSF, although the Senate has approved the nomination of Dr John Slaughter as the new director, he has yet to be sworn in by the President and it is possible that $\mathrm{Mr}$ Reagan will wish to propose another candidate for what is supposed to be a relatively non-partisan appointment.

In the Senate, much will depend on how the chairmanships of the various committtees are allocated. One of the most prominent election casualties was Senator Warren Magnussen, long-time representative of the state of Washington, who as chairman of both the Senate Appropriations Committee and its health subcommittee had presided over a period of substantially increased funds for biomedical research.

If the Democrats had retained control, the subcommittee chairmanship could have passed to Mr William Proxmire, the scrourge of NSF. As ranking Republican, however, the position could now be taken by Senator Mathias - unless he prefers to take over Mr Proxmire's committee, which is responsible for the budgets of both NSF and NASA.

NASA's hopes for a relatively sympathetic hearing in the Senate have also been raised by the likelihood that the chairmanship of the Commerce Committee's science, technology and space committee will pass to Republican Senator and former astronaut Jack Schmitt, a keen supporter of the space programme and of increased funds for space science.

In the House of Representatives, which remains in the hands of the Democrats, the main changes will result from a possible reorganization of the Science and Technology Committee, where three subcommittee chairmen - Mr Mike McCormack, Mr Jerome Ambro and $\mathrm{Mr}$ John Lloyd - all lost their seats.

David Dickson

\section{Polish unions}

\section{Science not lost}

\section{Gdańsk}

In spite of the legal wrangles over registration and the need to prepare contingency plans for a possible nationwide protest strike, Poland's new independent self-governing trade union, Solidarność, has already started work. Among other things, it established, at the end of last month, its All-Poland Coordinating Commission for Science.

This at first glance is somewhat surprising, because the present policy of Solidarność, as the very name implies, is to build a strong union organization without subdivisions by trade or profession. Profession-based branches were originally planned for a later stage. Such a policy meets with the aspirations of the many briefly established new unions which, after the creation of Solidarność in midSeptember, were quick to amalgamate with it. As Dr Zdzislaw Bibrowski, erstwhile chairman of the Independent Trade Union of Scientific, Technical and Educational Workers (founded 8 September - see Nature 18 September - merged with Solidarność 13 October) explained, the members felt that in the present fluid situation they needed greater bargaining power and protection than a single small union could afford.

The Solidarność commission for science is not intended to be a separate interest group but rather a working party to elaborate the union's practical suggestions on the strengthening and renewal of the role of science in Poland.

Such a renewal is widely accepted as a major factor in getting the Polish economy out of its present crisis. It was the theme of last month's extraordinary General Assembly of the Polish Academy of Sciences and of a number of statements by academic and scientific bodies throughout the country. Lech Walesa, the leader of
Solidarność, told me last week "Speeches and declarations are not the point. We need concrete activity."

Such activity will be the role of the Solidarność commission. As Dr Wojciech Gruszecki, a chemistry lecturer at the Gdańsk Technical University and the Solidarność spokesman on science and technology explained, the commission, which has already met several times in Poland's leading academic centres (Krakow, Warsaw, Gdańsk, Wroclaw) hopes to work out some concrete proposals and submit them to the government; so too during the next few months will the Academy of Sciences and the country's various learned bodies. New legislation on science in Poland is now being drafted and will shortly be presented to the Sejm (parliament). In the current atmosphere of greater "openness" a lively public debate is expected.

On many points, including the need for greater autonomy in academic life and the lifting of censorship restrictions, the scientific and academic community is unanimous. Solidarność, however, would go further. As Dr Gruszecki explained, the union urges that science be treated as a non-

\title{
University of Warsaw changes course
}

\section{Warsaw}

The expected liberalization of Polish academic life is not entirely a consequence of the Gdańsk accords, according to a spokesman for the Polish Ministry of Higher Education and Science. Rather, he said, it is the cumulation of a continuing process. Thus the promise of a greater degree of selfgovernment for the universities was already foreseen in guidelines drawn up several months ago.

The ministry, it appears, wishes to seem well abreast of developments. This has been expecially the case since the surprise resignation at the end of September of the rector of Warsaw University. With widespread talk of academic autonomy, the ministry found it prudent to offer a compromise solution for the appointment of his successor. It proposed a list of three candidates, from whom the university senate made its final selection.

The senate is now committed to the principle of academic autonomy. The pro-rector, Dr Kazimierz Dobrowolski, stresses that the university should be able to draw up its own syllabuses and courses. Even under the present system, he says, some latitude is possible. In his own subject, biology, the university has been able to initiate courses in such new fields as environmental biology and molecular genetics. The result, he says, is that no student can graduate with simply a nineteenth century knowledge of biology.

The academic staff at the university is nevertheless concerned with falling standards among candidates for entry. The educational reform, introduced three years ago, which replaced the traditional eight years of primary schooling and four years lyceum by a comprehensive ten-year schooling, alarmed both parents and university staff. Although three years is strictly too short a time in which to assess the new system, the Ministry of Education has been quick to read the signs. Although no official announcement has yet been made, a recent article in the weekly Perspektywy suggests that the new Minister of Education, Krzysztof Kruszewski, intends to revert to the former system, with certain changes in syllabus incorporated from the ill-fated ten-year system.

A recent development at Warsaw University has been the inauguration of a course of Friday evening lectures by members of the Society for Academic Courses (the "Flying University") whose aim is to fill the gaps left by the state system of instruction. The lectures, held in the Adam Mickiewicz Hall (the largest lecture room in the university) are not, however, formally sponsored by the Society for Academic Courses. The hall is leased to the new Independent Students' Union, which invited the speakers. But, as one of the student organizers said, the correspondence between the list of lecturers in the Mickiewicz Hall and the members of the Society for Academic Courses is hardly coincidental.

Vera Rich 